Araştırma makalesi

\title{
Büyük baraj projeleri ve bağlantılı yol inşaatları sonucunda Çoruh Nehri Havzasında oluşan arazi kayıplarının ve tahribatlarının belirlenmesi
}

\section{Determining loss and degradation of lands as a result of large dam projects and associated road constructions within the Coruh River Watershed}

\author{
Saim YILDIRIMER, Mehmet ÖZALP, Esin ERDOĞAN YÜKSEL \\ Artvin Çoruh Üniversitesi, Orman Fakültesi, Orman Mühendisliği Bölümü
}

Özet

Devlet Su İ̧̧leri'nin (DSi) halen devam eden “Çoruh Barajlar Projesi” kapsamında planlanan çok sayıda büyük baraj ve HES tesisinin inşası, Çoruh Nehri Havzası (ÇNH) üzerinde arazi kayıpları ve bozulmaları gibi ciddi değişimlere neden olmaktadır ancak bu değişimleri bilimsel olarak ortaya koyan veri miktarı ise oldukça kısıtıdır. Bu nedenle, hem barajların tamamlanarak su tutmaya başlaması hem de söz konusu baraj projeleri kapsamında yenilenen yolların inşaatları aşamalarında farklı amaçlarla kullanılan arazilerde meydana gelen/gelecek kayıpların/bozulmaların kısa sürede, güvenilir bir doğrulukla ve en az maliyetle tahmin edilmesi önemlidir. Böylece, akarsu yatağı boyunca havzalarda oluşabilecek bazı ciddi olumsuzlukların önceden bilinmesi ve sonrasında da bu havzaların yeniden planlanması sağlanabilir. Bu çalışmada, Çoruh Nehri'nin Artvin il sınırları içerisinde farklı aşamalarda olan (tamamlanan, inşası devam eden veya planlanan) 7 büyük baraj ve HES tesisi ile bağlantılı yol inşaatlarının neden olduğu/olacağı arazi kayıpları ve tahribatlarının saptanması amaçlanmıştır. Bu amaçla, Coğrafi Bilgi Sistemleri (CBS) yardımı ile meşcere ve CORıNE arazi örtüsü (CLC-2006) haritaları ile beraber tamamlanan bazı barajlardaki kamulaştırma verilerinden yararlanarak hem söz konusu barajlardan dolayı sular altında kalacak hem de yol inşaatları nedeni ile tahrip olacak arazilerin kullanım şekilleri ve alansal büyüklükleri ortaya konulmaya çalışılmıştır. Araştırma sonucunda barajların tümünün tamamlandığı varsayıldığında, farklı amaçlarla kullanılan yaklaşık 8137 ha alanın sular altında kalarak işlevlerini yitireceği tespit edilmiştir. Tüm bu alan içerisinde en büyük oranın orman (meşcere haritalarına göre \%62; CLC-2006 arazi örtüsüne göre \%52) niteliğindeki araziler, en küçük oranın ise yerleşim yeri (meşcere haritalarına göre $\% 0.77$, CLC-2006 arazi örtüsüne göre \%1.77) niteliğindeki araziler olduğu belirlenmiştir. Bunlara ilaveten Borçka, Deriner ve Artvin Barajlarından elde edilen istimlak/kamulaştırma (kadastro parselleri) verileri ile bu çalışmada kullanılan meşcere ve CLC-2006 haritalarından elde edilen veriler karşılaştırılmış ve iki veri kaynağı arasında farklılıklar olduğu görülmüştür. Ayrıca, Borçka ve Deriner Barajları nedeni ile yan yollar ve köy yolları dışında kalan ana yolların (tünel yapıları hariç) inşaatları sırasında ortaya çıkan hafriyatın gelişigüzel bir şekilde şevlerden aşağı atılması sonucunda tahrip olan arazi miktarının ise yaklaşık 413 ha civarında olduğu tahmin edilmiştir.

Anahtar kelimeler: Arazi kaybı ve tahribatı, büyük barajlar, CBS, CORINE, Çoruh Nehri Havzası, meşcere haritaları

\section{Abstract}

The Coruh Dams Project, an ongoing project planned by the State Water Affairs, involving several large dams and associated roads to be constructed along the Coruh River Valley, has been causing serious changes including land loss and degradation within the Valley, but the data on scientific estimations of such changes is very limited. Therefore, it is crucial to estimate areal amount of land loss and degradation due to both inundation of reservoir areas and improper road constructions with an easy and costeffective ways in order to realize the changes expected in the watershed before these projects are completed so that planning of watersheds can be initiated timely. In this study, the aim was to determine areal land loss and degradation caused by seven large dams at different stages (e.g. completed, under-construction or planned) and associated road constructions on the Middle and Lower Coruh Watershed within the city of Artvin. In order to find out the land use types and estimate areal sizes of lands inundated/damaged by these dams and improper road constructions, "forestry stand maps" and "CORINE Land Cover (CLC-2006)" along with data gathered from the processes of "compulsory purchases" for some of the completed dams were used. Estimates showed that when all the large dams are completed, according to two maps used in this research, approximately 8137 ha area with various land use types will be inundated and consequently lost. It was clearly seen that out of this total area the biggest ratio was forested lands (62\% according to the forest stand maps; $52 \%$ according to the CLC-2006) while the smallest ratio belonged to establishments ( $0.77 \%$ according to the forest stand maps; $1.77 \%$ according to the CLC-2006). In addition, when comparing the estimates from the forest stand maps and the CLC-2006 with the estimates calculated from the processes of compulsory purchases for Borcka, Deriner and Artvin Dams, it was determined that both maps did not revealed results that were close to the actual measurements gathered from the data of the compulsory purchases. In addition, it was estimated that approximately 413 ha of land was damaged due to improper road constructions where large amount of excavated materials was thrown down the very steep fill slope during the constructions of new roads (tunnel constructions were excluded) only for Borcka and Deriner dams

Key words: CORINE, Coruh River Watershed, forest stand maps, GIS, land loss and degradation, large dams 


\section{GíRiş}

Genel olarak içilebilir su ihtiyacı, kullanma suyu temini, elektrik enerjisi üretimi, sel ve taşkın kontrolü gibi ana amaçlarla inşa edilen büyük barajlar ve HES tesisleri yapıldıkları akarsuyun hidrografında (su rejimi) (WCD 2000; Maingi ve Marsh 2002; Stickler ve ark. 2013) ve sediment dağılımında (Gupta ve ark. 2012) farklılaşmalara, ayrıca akarsulardaki sucul canlıların tamamen veya kısmen yok olması veya değişmesi (Dudgeon 2005; Eker 2008), dere kenarı vejetasyonunun ve varsa endemik bitki türlerinin yok olması (Kellogg ve Zhou 2014), akarsu kenarlarındaki taşkın ovalarında yer alan tarım alanlarının ve bunlara bağı yerleşim alanlarının sular altında kalması (Zhao ve ark. 2010) ile burada yaşayan insanların zorunlu olarak göç ettirilmesi gibi ağır negatif sonuçlara da neden olmaktadır (Bayram ve Hazar 1994; WCD 2000; Wang ve ark. 2013).

Dünya Barajlar Komisyonu raporuna göre (WCD 2000), 1949 yılına kadar 5000 civarında olan büyük baraj sayısı dramatik bir yükseliş ile 20. yy sonunda 140 ülkede toplam 45000 rakamına ulaşmıştır. Hâlihazırda işletmede olan yaklaşık 350 büyük baraj ve yapımı planlanan 200'ü aşkın büyük baraj ile Türkiye ise son yıllarda en fazla baraj ve HES tesisi inşa eden ilk beş ülke arasında yer almaktadır (WCD 2000; DSi 2011). Hem Dünya'da hem de ülkemizde büyük baraj sayısındaki bu artış, barajların yapıldıkları bölgede neden olabilecekleri çevresel, sosyal ve ekonomik değişimlerin de daha geniş çaplı ve ciddi olmasına neden olmaktadır.

Büyük barajların etki alanı açısından neden oldukları en ciddi olumsuz sonuçlar arasında, inşa edildikleri akarsu havzasında yer alan mevcut arazilerin kaybı, tahribi veya kullanım şekillerindeki değişimler yer almaktadır (Özalp ve ark. 2009; Özalp ve ark. 2012; Yıldırımer ve ark. 2014). Baraj inşası tamamlandıktan sonra su tutma işleminin başlaması ile orman, mera, tarım, karayolu ulaşım ağları ve yerleşim yerleri sular altında kalarak mevcut vasıflarını ve işlevlerini kaybetmektedirler (Nilsson ve ark. 2005; Toker 2010; Sever 2010). Büyük barajların yapımında meydana gelen arazi kayıplarının tek nedeni oluşan rezervuarlarda tutularak meydana gelen geniş su kütleleri değildir. Buna ilave olarak, genelde vadi tabanlarında ve talveg çizgisine yakın bölgelerde yer alan mevcut karayolu ağının rezervuar su kotunun üstüne çıkarılması ile yapılması zorunlu olan yeni yol inşaatları da uygun tekniklerle yapılmadıkları takdirde önemli büyüklükte arazilerin tahrip olmasına neden olmaktadır (Toker 2010; Dehşet 2011). Yukarıda sıralanan arazi kayıplarının ve/veya tahribatlarının hızlı ve doğru bir şekilde ve en az maliyetle ortaya konulması konusunda Coğrafi Bilgi Sistemleri (CBS) son yıllarda kullanılan en etkin ve en yaygın yöntemlerden biridir (İnan 1998; Şensoy 2002; Sönmez 2004; Duran 2005; Genç ve Bostancı 2007; Kılıç ve ark. 2007; Gündoğan ve ark. 2008; Onur ve ark. 2009; Yıldırımer 2013). Benzer çalışmalarda farklı yıllara ait yüksek çözünürlüklü uydu görüntüleri ile (Güler ve ark. 2007) CORINE gibi arazi örtüsü veri tabanlarından (Kılıç ve ark. 2007) veya ülkemizde kullanılan meşcere haritalarından (Gündoğan ve ark. 2008; Yıldırımer 2013) yararlanılmaktadır. Ancak, yüksek çözünürlüklü uydu görüntülerinin oldukça maliyetli olmaları, arazi değişimlerini genel hatları ile ortaya çıkarmaya yönelik çalışmalarda çözünürlükleri düşük olmasına rağmen maliyetsiz olarak elde edilebilen meşcere haritaları veya CORINE gibi veri tabanlarının kullanılmasına yol açmıştır.

Çalışmamızda, Çoruh Nehri'nin orta ve aşağı kısımlarındaki ana ve yan kolları üzerinde yapılmış ya da yapılması planlanan toplam 7 büyük baraj ve bağlantılı yol inşaatları nedeni ile oluşmuş/oluşacak arazi kayıplarının ve tahribatlarının tespit edilmesi hedeflenmiştir. Bu amaçla, barajların sahip olduğu en yüksek su kotu temel alınarak meşcere ve CLC-2006 haritaları kullanılarak her bir barajın farklı vasıflardaki arazilerin ne kadarını sular altında bıraktığı veya bırakacağı hesaplanmıştır. Buna ilave olarak, barajların rezervuarları altında kalarak kullanılamaz hale gelen mevcut karayolu ağının yenilenmesi amacı ile yüzlerce km'lik yol inşaatları sonucunda tahrip olan araziler de 
iki örnek baraj, Borçka ve Deriner Barajları, temel alınarak belirlenmiştir. Ayrıca, arazi kayıpları konusunda bu çalışmada elde edilecek alan bazlı tahminler, söz konusu barajların inşası sırasında uygulanan kamulaştırma verileri neticesinde oluşan gerçek alan verileri ile karşılaştırılarak meşcere ve CLC2006 haritalarının benzer çalışmalardaki kullanımı sorgulanacaktır.

\section{MATERYAL VE YÖNTEM}

\section{Çalışma Alanı}

Çalışma alanı, Çoruh Nehri'nin Artvin il sınırları içerisinde farklı aşamalarda olan (tamamlanan, inşası devam eden veya planlanan) 7 büyük baraj ve HES tesisinin doğrudan veya dolaylı olarak etkisi altında kalan bölgedir (Şekil 1). Bilindiği üzere, Çoruh Nehri, ülkemizin en hızlı akan akarsuyudur ve yıllık ortalama 6.3 milyar $\mathrm{m}^{3}$ lük akış hacmine sahiptir. Toplam uzunluğu $431 \mathrm{~km}$ olan nehir yılda 5.8 milyon $\mathrm{m}^{3}$ rusubat (tortu, sediment) taşımaktadır. Çoruh Nehri'nin 410 km'lik kısmı Ülkemiz sınırları içerisinde, 21 km'lik kısmı ise Gürcistan sınırları içerisindedir (DSi 2005). Çoruh Nehri'nin Artvin'den geçen bölümünde, Artvin il merkezi dâhil Yusufeli ve Borçka ilçeleri ve bunlara bağlı çok sayıda köy ve mezra yer almaktadır. Arazi yapısı oldukça engebeli ve yüksek eğimli olduğundan Çoruh Vadisi'nde düzensiz bir yerleşim mevcuttur. Çoruh Nehri Havzası (ÇNH), denizden Artvin'e kadar Karadeniz, Artvin yakınlarından İspir yakınlarına kadar Akdeniz ve daha yüksek yerlerde de Doğu Anadolu iklimine geçişi ve Doğu Anadolu iklimi özelliklerini taşımaktadır (DSi 2007).
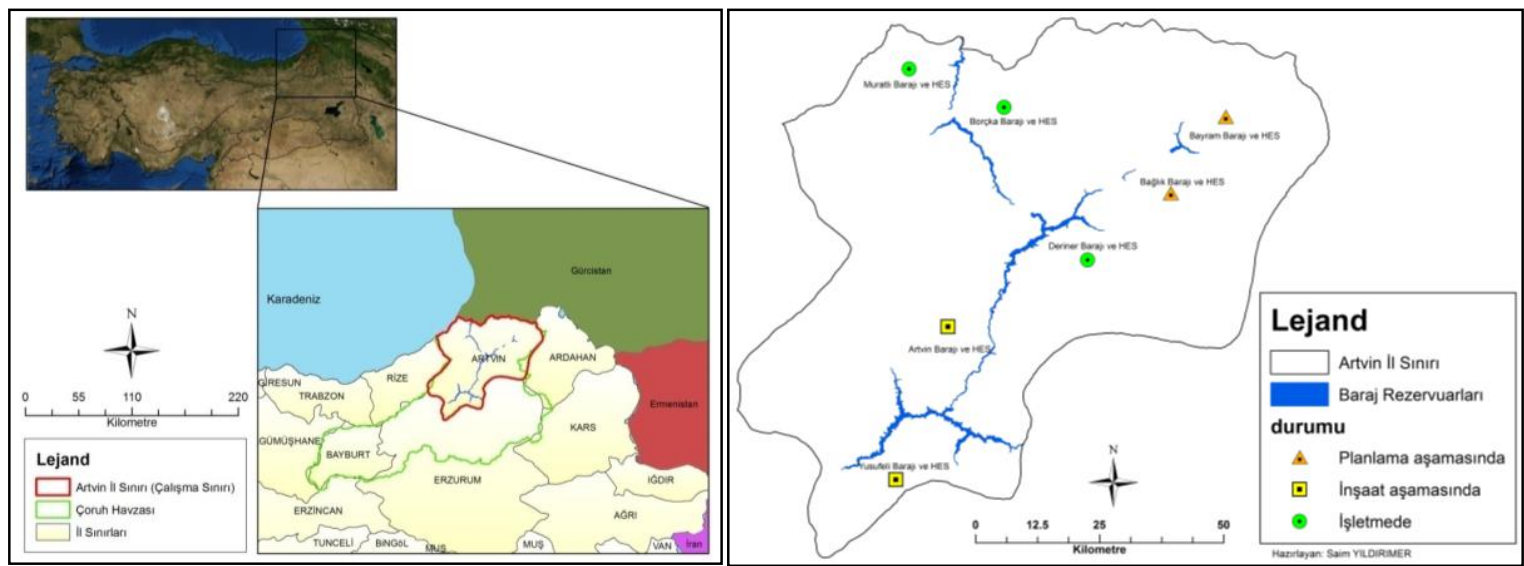

Şekil 1. Çalışma alanının genel konumu ile Çoruh Nehri'nin Artvin il sınırları içerisinde kalan bölümünde planlanan büyük barajların yapım aşamaları ve rezervuar alanları

\section{Yöntem}

Çalışmada, araştırma sahasındaki arazi kullanım şekilleri ve alansal olarak kayıp miktarlarının belirlenmesinde coğrafi bilgi sistemleri (CBS) teknolojisinden yararlanılmıştır. Haritaların elde edilmesinde ArcGIS 9.3 yazılımı kullanılmıştır. Uygulanan yöntemde öncelikle çalışma alanına ait haritalar (1/25000 ölçekli topografik ve 1985 tarihli meşcere haritaları) taranarak bilgisayar ortamına aktarılmıştır. Tarama işlemi yapılan haritalar referans noktaları kullanılarak UTM (UTM 6 derece) koordinat sistemine referanslandırılmış ve gerekli düzeltmeler yapılmıştır. Koordinatlandırma işlemi tamamlanan paftalar üzerinde sayısallaştırma işlemi yapılarak barajlara ait Devlet Su İşleri (DSi)'den temin edilen maksimum su kotlarına göre rezervuar alanları çizilmiştir. Barajların rezervuar alanları ile meşcere ve CLC-2006 haritaları çakıştırılarak su altında kalarak kaybolan arazilerin kullanım şekilleri alansal olarak ortaya çıkartılmıştır.

Meşcere ve CLC-2006 haritalarında arazi kullanım durumu farklı sınıflama tekniklerine göre sınıflandırımıştır. Bu uyumsuzluğu gidermek ve karşılaştırmaları sağlıklı bir şekilde yapabilmek 
amacıyla her iki haritadaki çok sayıda sınıflama, CLC2006 haritasında yer alan 1. Düzey (Yapay Bölgeler, Tarım Alanları, Orman ve Yarı Doğal Alanlar, Sulak Alanlar ve Su Kütleleri ) sınıflama altında 4 ana grupta toplanmıştır. Arazi kullanım şekilleri ile kayıp miktarları tahmin edilirken, yararlanılan meşcere haritalarının barajların tamamlanma tarihinden önce olmasına dikkat edilmiştir.

Büyük barajların yapımında mevcut karayolu ağının rezervuar su kotunun üstüne çıkarılması ile meydana gelen arazi tahribatının boyutunu ortaya çıkarmak üzere -ulaşımın tüneller aracılığı ile yapıldığı kısımlar dışında- yeniden inşa edilen yollar ile baraj rezervuarının maksimum su kotu arasında kalan alan hesaplanmıştır. Hesaplanan bu alandaki arazilerin kullanım şekillerini belirlemek amacı ile meşcere ve CLC-2006 haritaları kullanılmış ve elde edilen sonuçlar her iki haritaya göre karşılaştırılmıştır (Tablo 6).

\section{BULGULAR}

Inşası devam eden veya tamamlanan farklı aşamalardaki her bir barajın ÇNH'da mevcut arazi kullanımı başta olmak üzere sosyal ve ekonomik etkiler gibi birtakım değişimlere neden olduğu ve olacağı açıkça görülmektedir. Hesaplamalar göstermiştir ki; söz konusu barajların tümünün tamamlandığı varsayıldığında yaklaşık 8137 ha alanın sular altında kalacağı öngörülmektedir. Bu alanlardan en büyük oranın \%62 (5015 ha) ile orman, en küçük oranın ise
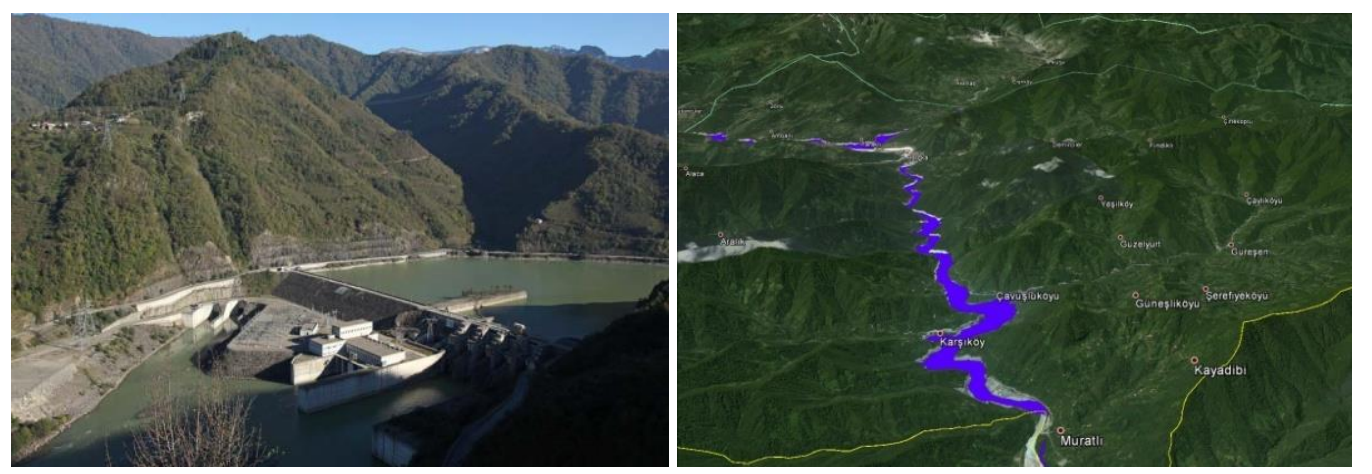

Şekil 2. Muratlı Barajı’nın gövde kısmı ile su tutulma aşamasından sonra oluşan rezervuar alanından görünüm
\%0.8 (63 ha) ile yerleşim alanları olduğu tespit edilmiştir.

\section{Barajların Neden Olduğu Arazi Kayıpları}

Çoruh Nehri'nin orta ve aşağı bölümlerinde yer alan ve Artvin il sınırları içerisinde yapılması planlanan toplam 7 büyük barajın en yüksek su tutma kotlarına göre tahmin edilen arazi kayıpları aşağıda listelenmiştir.

\section{Muratlı Barajı ve HES}

Muratlı Barajı (Şekil 2) 2005 yılında tamamlanmış ve aynı yıl su tutmaya başlamıştır. Bu nedenle, neden olduğu arazi kullanım değişiminin ortaya konması için güncel dönemin meşcere haritasında su olarak görüldüğünden önceki döneme (1985 yılı) ait meşcere haritasından yararlanılmıştır. CLC-2006 arazi örtüsü haritası da bu barajın tamamlanma tarihinden sonra oluşturulduğundan bu barajın arazi kullanım değişimi hesabında kullanılamamıştır. Meşcere haritası kullanılarak yapılan çakıştırmalar neticesinde Muratı Barajı ile toplam 426.1 ha'lık bir alanın sular altında kaldığı belirlenmiştir (Tablo 6).

Yapılan söz konusu hesaplamalarda en büyük arazi kayıplarının sırası ile su ve tarım alanlarında olduğu görülmektedir. Meşcere haritasına göre su ile ifade edilen kısım en yüksek (\%53) değeri oluşturmaktadır. Bunun nedeni vadi tabanının geniş olduğu yerlerde nehir yatağının geniş bir alanı kaplaması ve içerisinde kumul olarak belirtilen alanların da bu sınıfa dâhil edilmesinden kaynaklanmaktadır. 


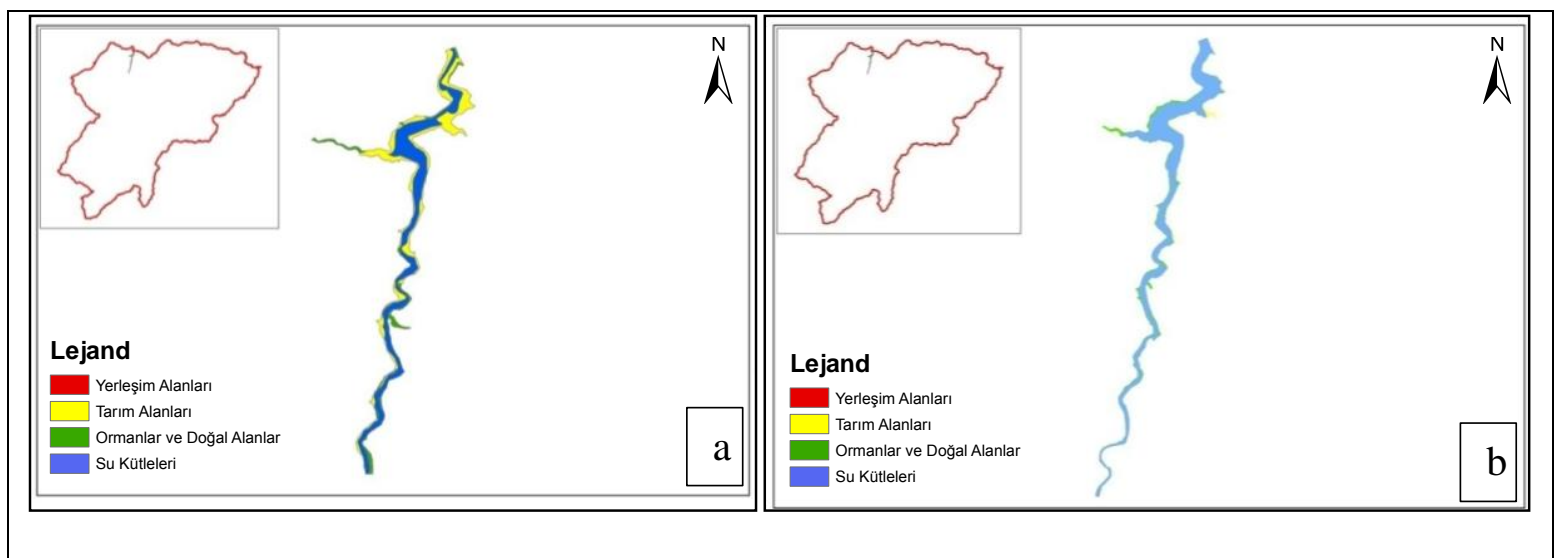

Şekil 3. Muratı Barajı ve HES tesisine ait meşcere (a) ve CLC-2006 arazi kullanım haritaları (b)

\section{Borçka Barajı ve HES}

Borçka Barajı (Şekil 4), Aşağı Çoruh Havzasının ikinci barajıdır ve Borçka İlçesinin $2.5 \mathrm{~km}$ membasındadır. Bu barajın su tutmayı tamamlaması Muratı barajından sonra olduğundan CLC-2006 haritasına göre tamamı su olarak görülmektedir. Güncel meşcere haritasına göre de arazi kullanım durumu su olarak görüldüğünden önceki döneme ait meşcere haritaları (1985)

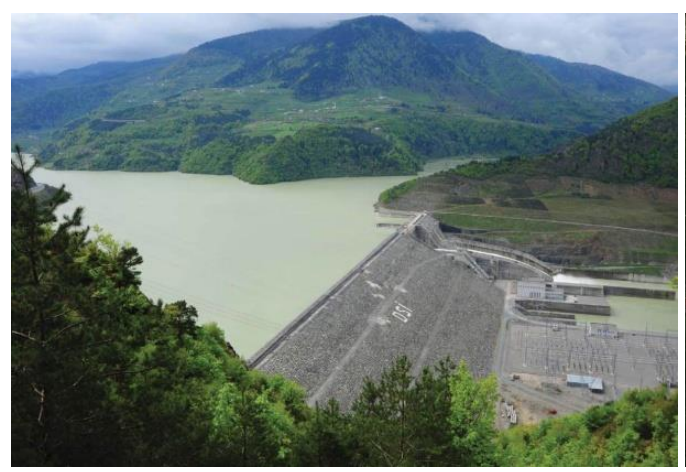

kullanılmıştır. Yine burada da su alanının fazla olmasının nedeni geniş olan nehir yatağındaki kumul alanlarının su alanları ile birleştirilmesindendir. Hesaplamalara göre toplam 1029 ha'lık bir alanın sular altında kaldığı ve meşcere haritasına göre incelendiğinde en yüksek değerin \%43 ile orman niteliğindeki araziler ve en küçük değerin ise \%16 ile ziraat- yerleşim yeri niteliğindeki araziler olduğu görülmektedir.

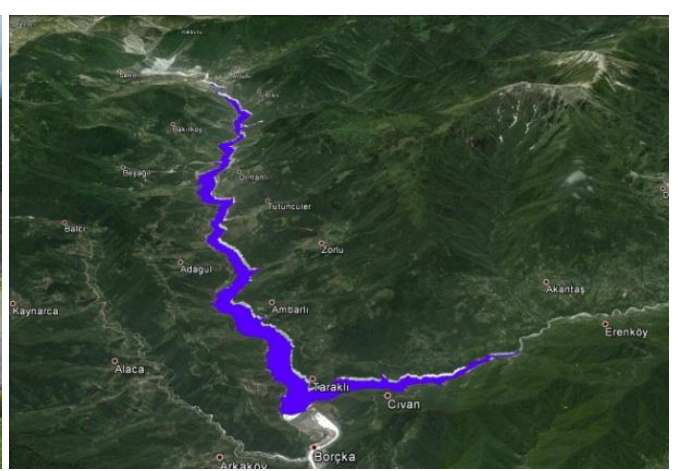

Şekil 4. Borçka Barajı́nın gövde kısmı ile su tutulma aşamasından sonra oluşan rezervuar alanından görünüm

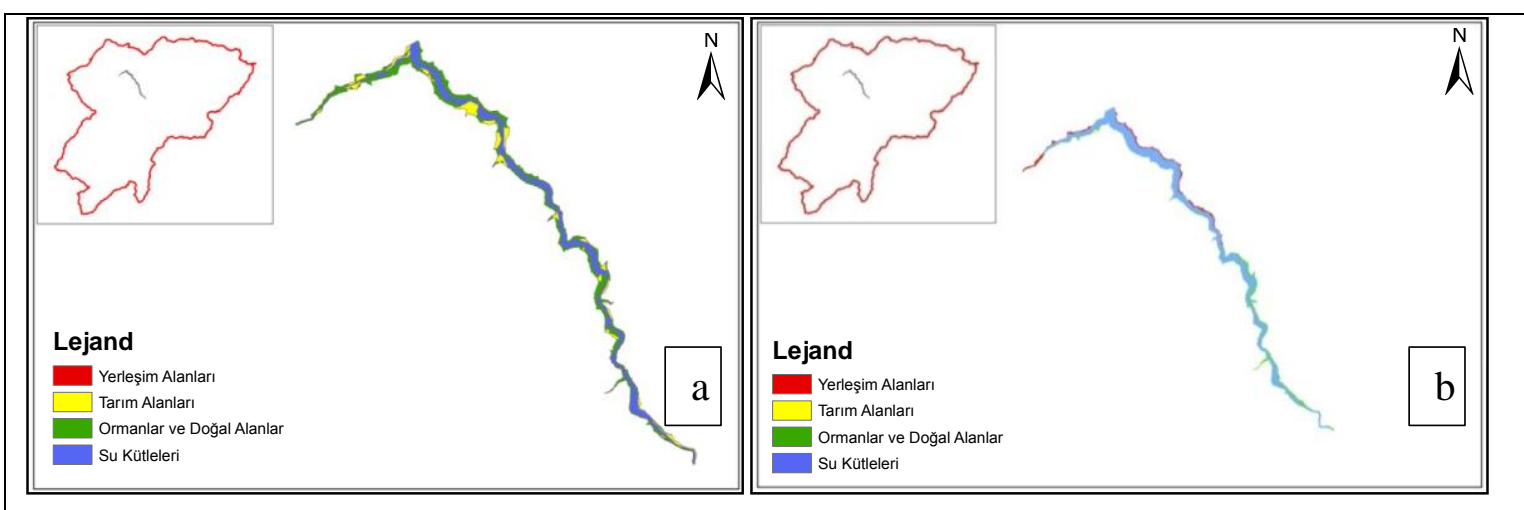

Şekil 5. Borçka Barajı ve HES tesisine ait meşcere (a) ve CLC-2006 arazi kullanım haritaları (b) 


\section{Deriner Barajı ve HES}

Deriner Barajı (Şekil 6), 253 metre yüksekliğiyle Türkiye'nin en yüksek, dünyanın üçüncü yüksek barajıdır. Artvin-Erzurum karayolu üzerindeki köprünün $5 \mathrm{~km}$ membasındadır. Türkiye'nin en yüksek su düşüsüne sahip olan Deriner Barajı 2012 yılının sonlarında açılmıştır. Baraj rezervuarı altında kalan alanlar meşcere haritasına göre incelendiğinde en büyük alanın $\% 73$ ile orman niteliğindeki alanlarda olduğu ve en küçük alanın ise \%8 ile su vasfında olduğu görülmektedir (Tablo 6). CLC-2006 arazi örtüsü haritasına göre incelendiğinde ise yine en yüksek değerin \%63 ile orman ve \%17 ile en küçük değerin su vasfında olduğu görülmektedir (Tablo 6).
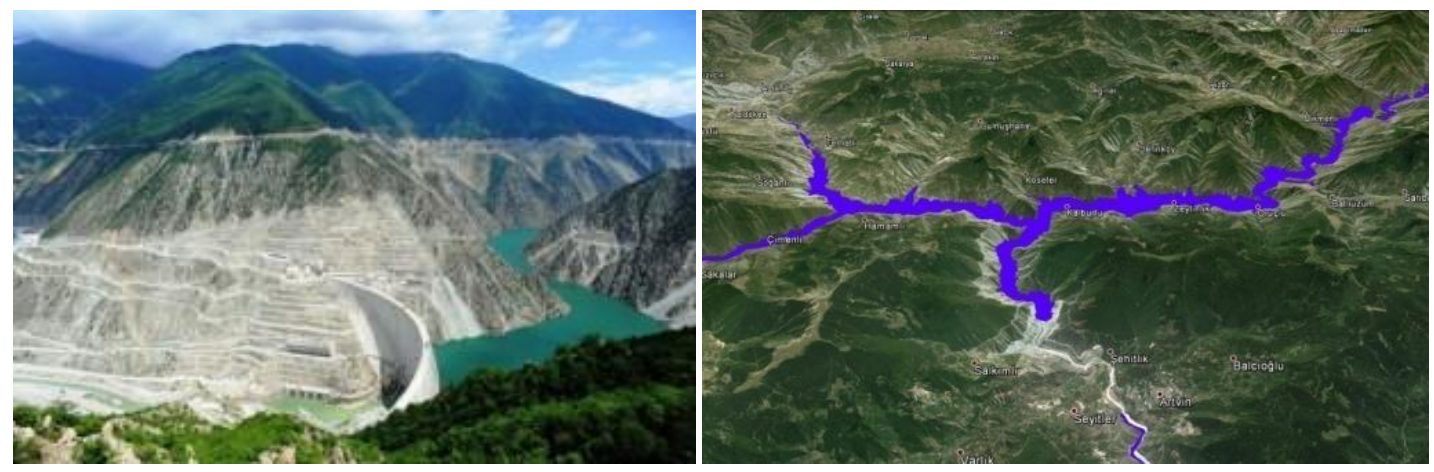

Şekil 6. Deriner Barajı’nın gövde kısmı ile su tutulma aşamasından sonra oluşan rezervuar alanından görünüm

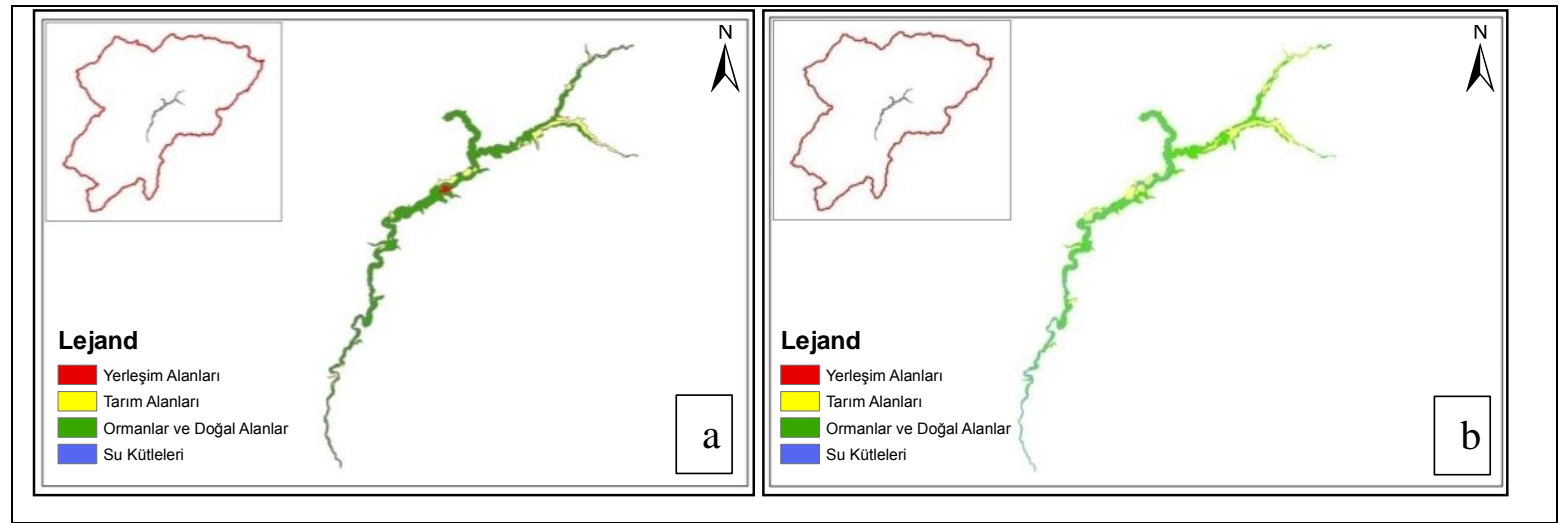

Şekil 7. Deriner Barajı ve HES tesisine ait meşcere (a) ve CLC-2006 arazi kullanım haritaları (b)

\section{Artvin Barajı ve HES}

Orta Çoruh Havzasının ikinci ve son barajı olan Artvin Barajı, Yusufeli İlçesinin $30 \mathrm{~km}$ ve Çoruh Nehrinin büyük kollarından biri olan Oltu Çayı birleşiminin $20 \mathrm{~km}$ mansabındadır (DSi 2005).

Artvin Barajı ve HES Projesinin inşasına 2011 yılında başlanmıştır. Tamamlandığında ise yaklaşık 410 ha'lık bir alanı sular altında bırakacaktır. Bu alanları meşcere haritasına göre (Şekil 8) en fazla \%83 ile orman alanları ve en düşük \%1 ile yerleşim alanları oluşturmaktadır
(Tablo 6). CLC-2006 haritasına göre en yüksek değer $\% 48$ ile su kütleleri olarak ifade edilen sınıflamaya girerken en küçük değer ise \%16 ile tarım alanları olmaktadır (Tablo 6). CLC-2006 sınıflamasına göre su vasfına giren değerin büyük çıkmasının nedeni; CLC2006 sınıflamasında kullanılan uydu görüntülerinin çözünürlüğünün düşük olması ve buna bağlı olarak dik ve derin bir vadiye sahip olan rezervuar sahasının nehir yatağının mevsimsel değişiminde etkisiyle geniş bir alan kaplaması olarak tahmin edilmektedir (Bossard ve ark. 2000). 


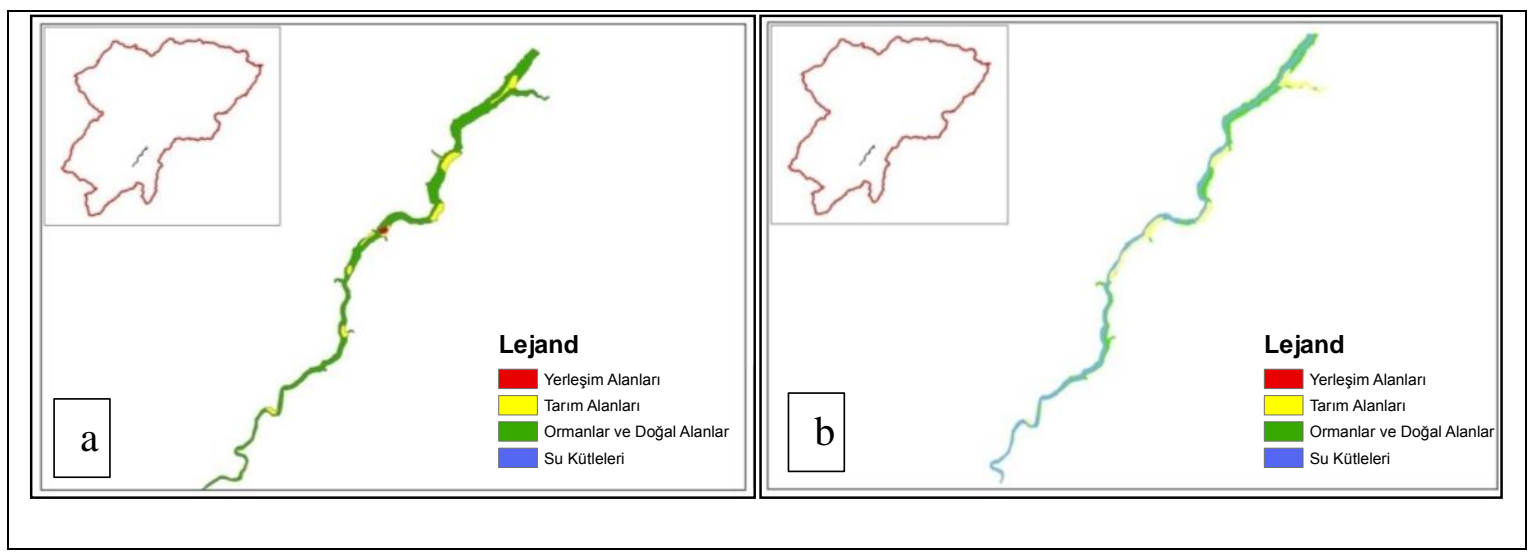

Şekil 8. Artvin Barajı ve HES tesisine ait meşcere (a) ve CLC-2006 arazi kullanım haritaları (b)

\section{Yusufeli Barajı ve HES}

Orta Çoruh Havzasının ilk barajı olan Yusufeli Barajı, Yusufeli ilçesinin $10 \mathrm{~km}$ ve Oltu Çayı birleşiminin 800 metre mansabındadır (DSi 2005). Çoruh Havzası üzerinde inşasına 2013 yılı itibariyle başlanan Yusufeli Barajı ve HES, tamamlandığında yaklaşık 3219 ha'lık bir alanı sular altında bırakacaktır. Meşcere haritasına göre (Şekil 9) incelendiğinde rezervuar sınırları içerisinde kalan en büyük alanın \%62 ile orman niteliğinde olduğu ve en küçük alanın ise \%0.8 ile yerleşim alanları olduğu görülmektedir (Tablo 6). CLC2006 arazi sınıflamasına göre ise en büyük alanın \%56 ile orman niteliğinde ve en küçük alanın ise \%0.8 ile su vasfında olduğu görülmektedir (Tablo 6).

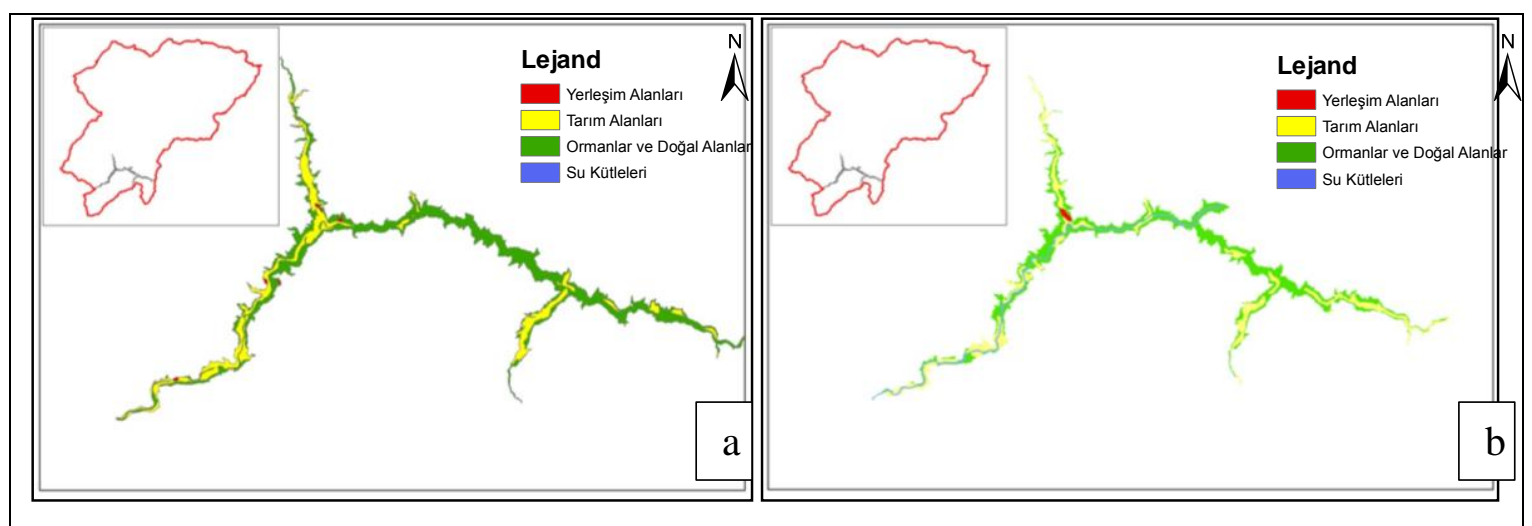

Şekil 9. Yusufeli Barajı ve HES tesisine ait meşcere (a) ve CLC2006 arazi kullanım haritaları (b)

\section{Bayram Baraji ve HES}

Çoruh Nehrinin Berta Çayı kolu üzerindeki ikinci baraj olan Bayram Barajı, su kavuşumunun $32 \mathrm{~km}$ membasındadır. Proje aşamasında olan bu baraj hayata geçirildiği takdirde yaklaşık 345.5 ha'lık bir alanı sular altında bırakacaktır. Meşcere haritasına göre (Şekil 10) bu alanın \%76'sını ormanlık alan ve \%24'ünü de tarım alanları oluşturmaktadır (Tablo 6). CLC-2006 sınıflamasına göre ise alanın \%94.5'inin orman vasfında, \%5.5 tarım alanı olduğu görülmektedir (Tablo $6)$. 


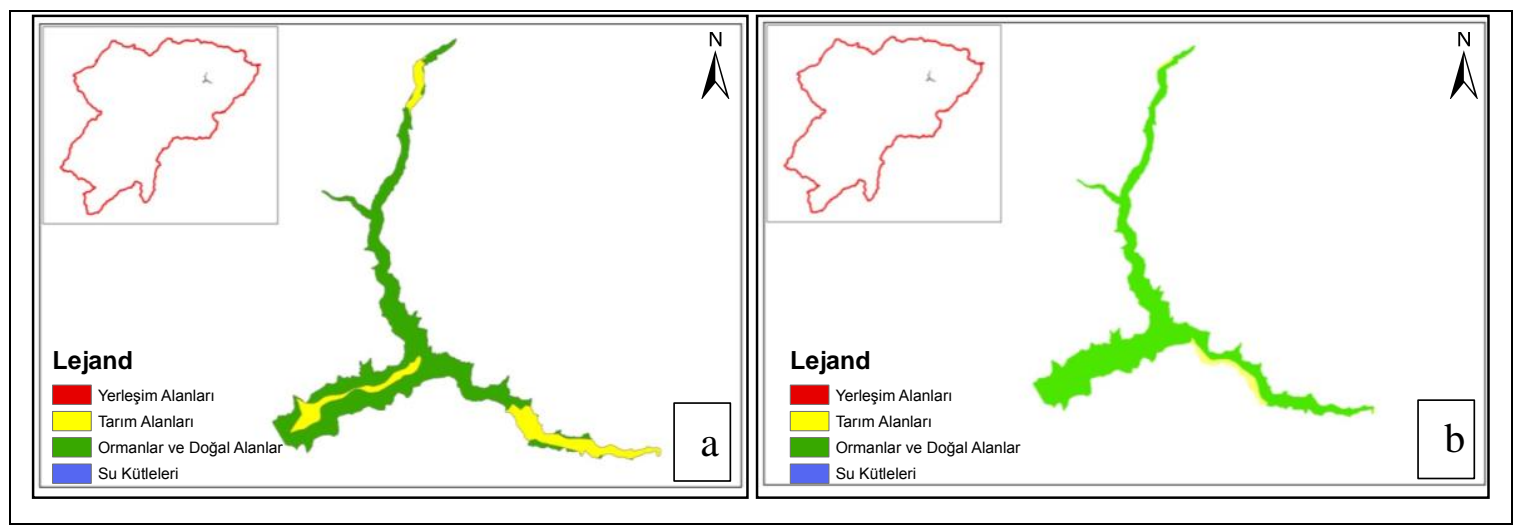

Şekil 10. Bayram Barajı ve HES tesisine ait meşcere (a) ve CLC-2006 arazi kullanım haritaları (b)

\section{Bağlık Barajı ve HES}

Çoruh Nehrinin Berta Çayı kolu üzerindeki ilk baraj olan Bağlık Barajı, su kavuşumunun 12 km membasındadır. 2005 yılında Çoruh Nehri Baraj Projelerine dâhil edilen Bağlık Barajı ve HES plana göre hayata geçirildiğinde yaklaşık 36 ha'lık bir alanı sular altında bırakacaktır. Bu alanın meşcere haritasına göre (Şekil 11) \%97.5 orman ve \%2.5 ziraat-iskân olduğu görülmektedir (Tablo 6). CLC-2006 sınıflamasına göre alanın tamamının orman vasfında olduğu görülmektedir (Tablo 6).

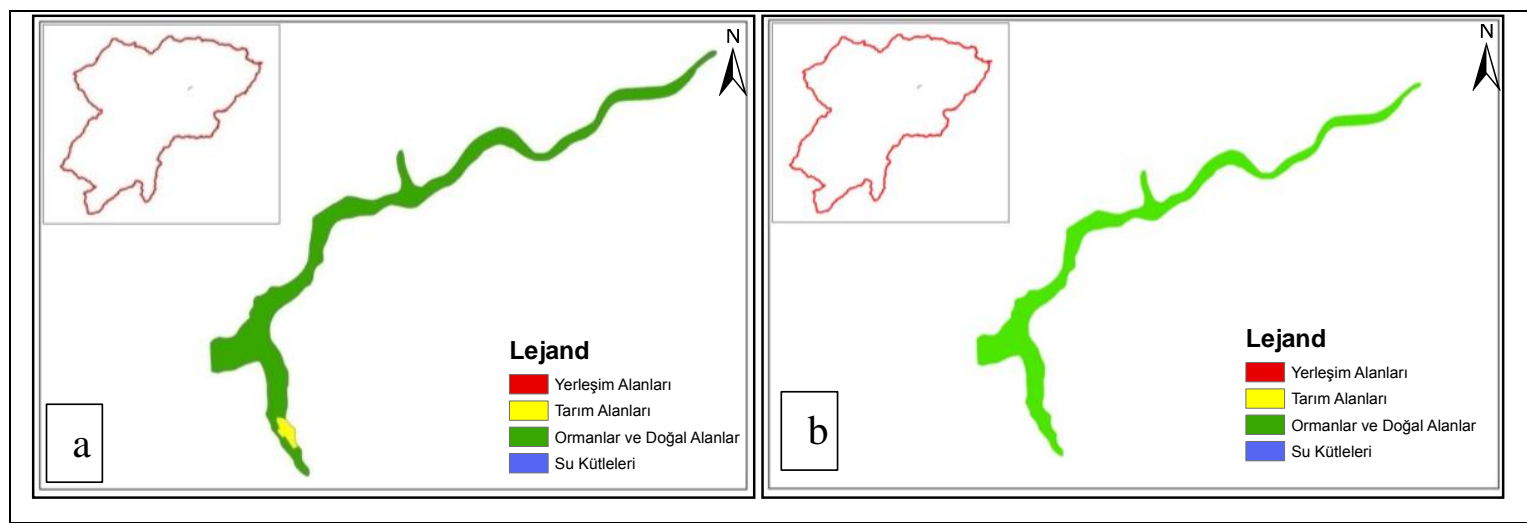

Şekil 11. Bağlık Barajı ve HES tesisine ait meşcere (a) ve CLC-2006 arazi kullanım haritaları (b)

\section{Yöntemlerin Karşılaştırılması}

Yapılan çalışmada, barajların rezervuar sahalarına ait meşcere haritaları ve CLC-2006 arazi örtüsü veri tabanından yararlanılmıştır. Ayrıca tamamlanan bazı barajlarda uygulanan istimlak/kamulaştırma çalışmalarına ait parsel bazında veriler de ilgili kurumlardan elde edilmiştir. Buradan yola çıkarak, bu çalışmada kullanılan meşcere haritaları ve CLC-2006 arazi örtüsü veri tabanından elde edilen veriler, kamulaştırma çalışmaları tamamlanmış olan Borçka, Deriner ve Artvin barajlarının rezervuar sahalarına ait kadastro parsellerinden elde edilen veriler ile karşılaştırılmıştır. Böylece, meşcere haritaları ve CLC2006 arazi örtüsü veri kaynaklarından hangisinin daha doğru sonuçlar verdiği ve benzer çalışmalarda kullanılabilme olanakları konusunda yardımcı veriler sunulmuş olacaktır. Söz konusu bu karşılaştırmalar kamulaştırma çalışmaları sona eren üç örnek baraj projesi için aşağıda alt başlıklar halinde irdelenmiştir.

\section{Borçka Barajı ve HES Rezervuar Sahasına Ait Karşılaştırma}

Borçka Barajı 2005 yılında su tutmayı tamamlamış ve ardından enerji üretimine başlamıştır. Bu tarihten önce kamulaştırılan kadastro parsellerine ait arazi kullanım şekilleri (Şekil 12) ve alansal büyüklük verileri ile meşcere haritası ve CLC-2006 haritalarından yararlanılarak ortaya çıkarılan veriler karşılaştırılmıştır 
(Tablo 1). Tablo 1'den de görüleceği üzere hem meşcere hem de CLC-2006 verileri ile kamulaştırma verileri arasında önemli farklar olduğu anlaşılmaktadır. CLC2006 haritası açısından ortaya çıkan farkın ana nedeni olarak bu haritanın Borçka Barajının su tutma işleminden sonra üretilmesi/güncellenmesi gösterilebilir (Tablo 1). Bununla beraber, meşcere haritasına göre kaybolan yerleşim alanının olmaması ise meşcere haritalarında yerleşim birimlerinin ziraat alanları ile birlikte ifade edilmesinden kaynaklandığı söylenebilir. Tarım alanları açısından da önemli farklılıklar olduğu tespit edilmiştir ki meşcere haritasına göre 167.2 ha olarak hesaplanan tarım alanı miktarı, CLC-2006 arazi örtüsü veri tabanına göre ise yalnızca 26.2 ha bulunmuştur. Buna karşılık kamulaştırılan gerçek alan 263.1 ha olarak rapor edilmiştir.

Tablo 1. Borçka Barajı rezervuar sahası altında kalan arazi şekilleri ve alansal büyüklüklerinin meşcere, CLC-2006 ve kamulaştırma verileri ile karşılaştırılması

\begin{tabular}{lccc}
\hline Tipi & Meşcere Haritası Alan (ha) & CLC-2006 Alan (ha) & Kamulaştırma Alan* (ha) \\
\hline Yerleşim Alanları & 0 & 69.7 & 15 \\
Tarım Alanları & 167.2 & 26.2 & 263.1 \\
Ormanlar ve Doğal Alanlar & 437.3 & 95 & 625.3 \\
Diğer & 424.7 & 838.3 & 125.8 \\
Toplam & 1029.2 & 1029.2 & 1029.2
\end{tabular}

*(Toker, 2010)

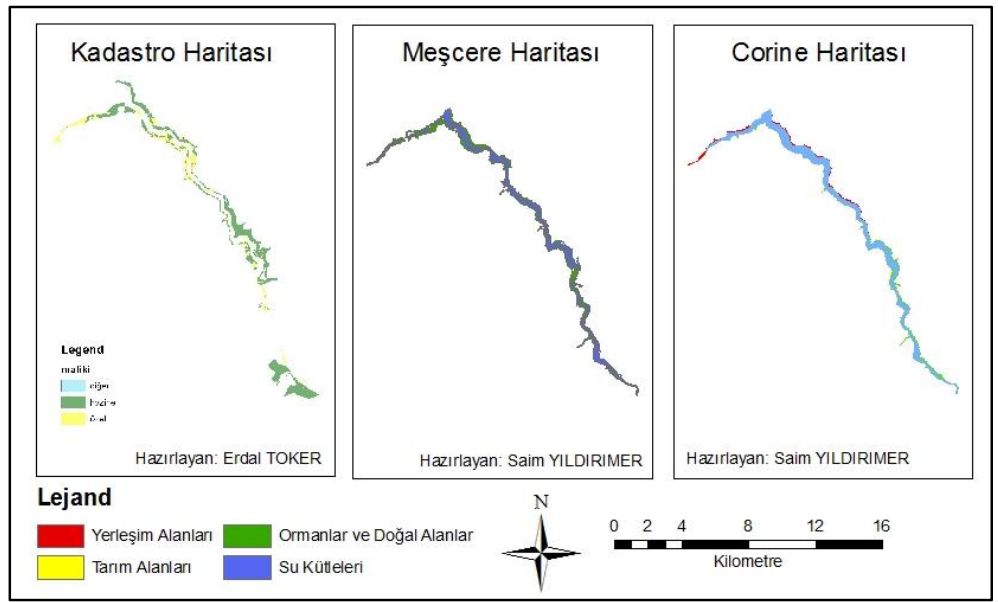

Şekil 12. Borçka Barajı ve HES rezervuar sahasına ait kullanılan haritaların karşılaştırııması

\section{Deriner Barajı ve HES Rezervuar Sahasına Ait}

\section{Karşılaştırma}

Deriner Barajı rezervuar sahası için kadastro parselleri ile yapılan karşılaştırmada (Şekil 13) CLC-2006 haritasına göre yerleşim alanları bulunmazken meşcere haritasında 34.8 ha ve kamulaştırılan kadastro parsellerinde ise 95.9 ha olmuştur. Yerleşim birimlerinin ÇNH boyunca dağınık halde bulunması ve alanlarının genel olarak 25 ha'dan küçük olması, bu alanların CLC-2006 arazi örtüsü veri tabanında ayrı bir kullanım şekli olarak belirtilmemesine ve dolayısı ile çalışma sonucunda kayıp alanlar içerisinde gösterilmemesine neden olduğu düşünülmektedir. Ayrıca, tarım alanları ile iç içe bulunan iskan alanları meşcere haritalarında "ziraat-iskan" şeklinde ifade edilmektedir. Bu alanlar ise yapılan sınıflamada tarım alanlarına dahil edilmiştir. Bu nedenle meşcere haritasında kamulaştırılan alanlara göre 50 ha'lık bir fark bulunmaktadır. Orman alanları açısından bir karşılaştırma yapıldığında oldukça anlamlı farkların bu arazi kullanım şekli için de ortaya çıktığı görülmektedir (Tablo 2). Bunun nedenlerinden biri olarak kamulaştırmaya dahil olmayan tescil dışı alanların bulunması gösterilebilir. Örneğin, su yüzeyleri, kayalıktaşlık alanlar, yollar, şalt sahaları tescil dışı alanlara 
dahil olmaktadır. Bununla birlikte, kamulaştırma çalışmaları yapılırken nehir yataklarının kenarları nehrin mevsimsel olarak yükselmesi göz önünde bulundurularak geniş bırakılmıştır. Tablo 2'de "Diğer" satırında ifade edilen 873.3 ha'lık değer bu alanları oluşturmaktadır.

Tablo 2. Deriner Barajı rezervuar sahası altında kalan arazi şekilleri ve alansal büyüklüklerinin meşcere, CLC2006 ve kamulaştırma verileri ile karşılaştırılması

\begin{tabular}{lccc}
\hline Tipi & Meşcere Haritası Alan (ha) & CLC-2006 Alan (ha) & Kamulaştırma Alan* (ha) \\
\hline Yerleşim Alanları & 34.8 & 0 & 95.9 \\
Tarım Alanları & 469 & 535.6 & 671 \\
Ormanlar ve Doğal Alanlar & 1945.7 & 1679.9 & 1030.8 \\
Diğer & 221.5 & 455.5 & 873.3 \\
Toplam & 2671 & 2671 & 2671 \\
\hline
\end{tabular}

*(Toker, 2010)

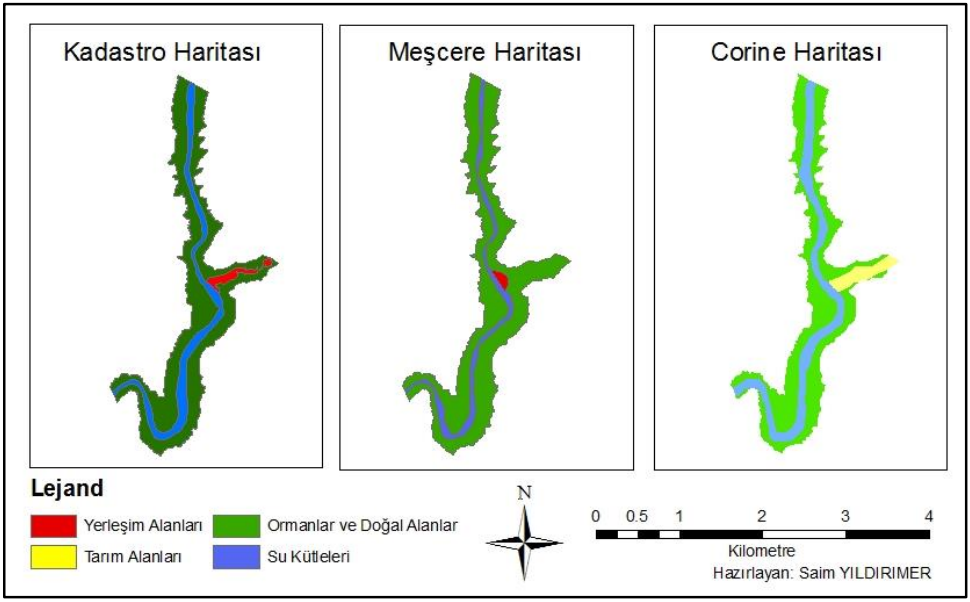

Şekil 13. Deriner Barajı ve HES rezervuar sahasına ait kullanılan haritaların karşılaştırılması

\section{Artvin Barajı ve HES Rezervuar Sahasına Ait Karşılaştırma}

Kamulaştırma çalışmaları tamamlanan Artvin Barajı rezervuar sahası için yapılan karşılaştırmada hem istimlak çalışmalarında hem de CLC2006 arazi örtüsü haritasına göre yerleşim birimleri bulunmazken meşcere haritasında 3.7 ha'lık bir alanın olduğu tespit edilmiştir (Tablo 3). Kamulaştırılan tarım alanları miktarı 79.2 ha iken meşcere haritasında 60.4 ha ve CLC2006 haritasında 66.2 ha olarak belirlenmiştir ve bu açıdan birbirine yakın sonuçlar olduğu söylenebilir. Buna karşılık, orman alanları açısından değerlendirildiğinde kamulaştırılan ormanlık alanın 274.4 ha, sular altında kalan ormanlık alanın ise meşcere haritasına göre 345.9 ha ve CLC2006 haritasına göre 145.6 ha olduğu hesaplanmış ve her bir sonucun birbirinden farklı olduğu görülmüştür. Ancak, tescil dışı (diğer) alanların CLC2006 ve kamulaştırma değerlerine eklenmesi ile aslında her bir veri kaynağından elde edilen ormanlık alan miktarlarının birbirine yaklaştığı gerçeği de göz ardı edilmemelidir (Şekil 14). Ayrıca, CLC2006 haritasında ormanlık alanların düşük ve diğer alanların fazla çıkmasının bir nedenin de hem kamulaştırma çalışmalarında hem de meşcere haritasında nehir yatağı olarak bir ayrım yapılmamışken CLC2006 haritasında önemli bir alan (198.2 ha) nehir yatağı (diğer kategorisinde) olarak belirtilmiştir. 
Tablo 3. Artvin Barajı rezervuar sahası altında kalan arazi şekilleri ve alansal büyüklüklerinin meşcere, CLC2006 ve kamulaştırma verileri ile karşılaştırılması

\begin{tabular}{llll}
\hline Tipi & Meşcere Haritası Alan (ha) & CLC-2006 Alan (ha) & Kamulaştırma Alan* (ha) \\
\hline Yerleşim Alanları & 3.7 & 0 & 0 \\
Tarım Alanları & 60.4 & 66.2 & 79.2 \\
Ormanlar ve Doğal Alanlar & 345.9 & 145.6 & 274.4 \\
Diğer & 0 & 198.2 & 56.4 \\
Toplam & 410 & 410 & 410 \\
\hline
\end{tabular}

*Doğuş Enerji Üretim ve Tic. A.Ş.

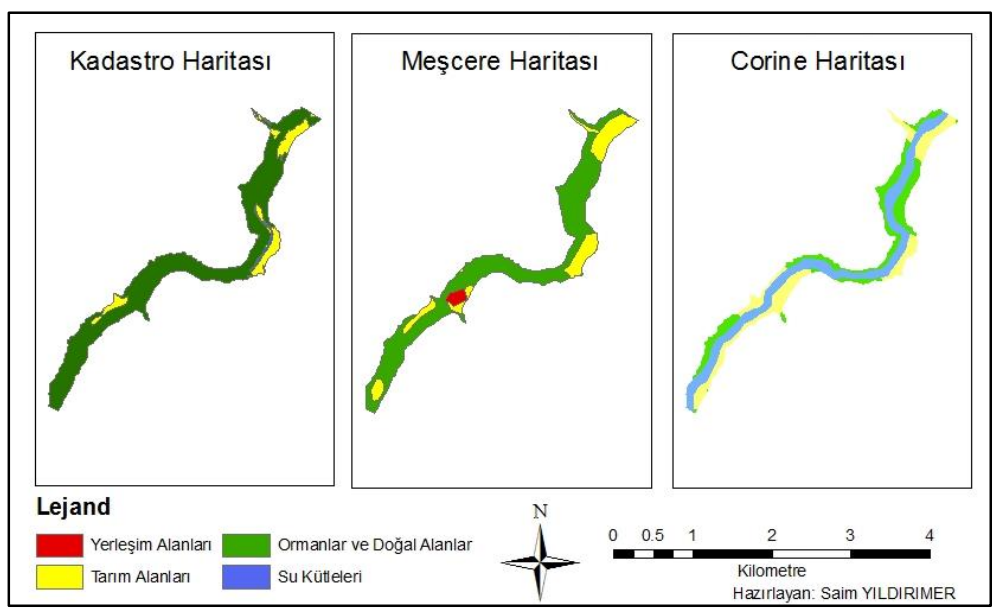

Şekil 14. Artvin Barajı ve HES rezervuar sahasına ait kullanılan haritaların karşılaştırılması

Sonuç olarak, yukarıda yapılan yöntem karşılaştırmasında, meşcere haritaları ve CLC-2006 arazi örtüsü veri tabanından yararlanılarak yapılan arazi kayıp tahminlerinin, bazı barajlarda uygulanan istimlak/kamulaştırma çalışmalarından elde edilen verilerden kısmen farklı sonuçlar verdiği tespit edilmiştir.

\section{Rezervuar Sahası Altında Kalan Ormanlar ve Doğal Alanların Sınıflandırılması}

Baraj rezervuar sahası altında kalan ormanlar ve doğal alanlar (Tablo 6) meşcere haritasından yararlanılarak verimli ve verimsiz ormanlar, meralar, orman toprağı (orman içi açıklıklar) ve diğer olmak üzere nitelendirilerek sınıflandırılmış ve her bir sınıfın yüzde bazında oranları belirtilmiştir (Tablo 4).

Tablo 4. Rezervuar sahası altında kalan orman ve doğal alanlar (\%)

\begin{tabular}{|c|c|c|c|c|c|c|c|}
\hline & $\begin{array}{c}\text { Muratlı Barajı } \\
\text { ve HES (\%) }\end{array}$ & $\begin{array}{c}\text { Borçka Barajı } \\
\text { ve HES (\%) }\end{array}$ & $\begin{array}{c}\text { Deriner Barajı } \\
\text { ve HES (\%) }\end{array}$ & $\begin{array}{c}\text { Artvin Barajı } \\
\text { ve HES (\%) }\end{array}$ & $\begin{array}{c}\text { Yusufeli Barajı } \\
\text { ve HES (\%) }\end{array}$ & $\begin{array}{c}\text { Bayram Barajı } \\
\text { ve HES (\%) }\end{array}$ & $\begin{array}{c}\text { Bağlık Barajı } \\
\text { ve HES (\%) }\end{array}$ \\
\hline $\begin{array}{l}\text { Verimli } \\
\text { Orman }\end{array}$ & 10 & 2 & - & - & 1 & 0,3 & 0,7 \\
\hline $\begin{array}{l}\text { Verimsiz } \\
\text { Orman }\end{array}$ & 90 & 91 & 100 & 100 & 24 & 99,7 & 99,3 \\
\hline Mera & - & - & - & - & 9 & - & - \\
\hline $\begin{array}{l}\text { Orman } \\
\text { Toprağı }\end{array}$ & - & 1 & - & - & 66 & - & - \\
\hline Diğer & - & $6^{*}$ & - & - & - & - & - \\
\hline
\end{tabular}

* Hatila Vadisi Milli Parkı

Ormanlık alanlar nitelendirilirken bozuk, çok bozuk ve baltalık alanlar verimsiz, mera ve orman toprağı dışında kalan diğer tüm çap ve kapalılık sınıfına sahip alanlar ise verimli olarak sınıflandırılmıştır. Tablo 4 irdelendiğinde, su altında kalarak kaybolan ormanlık alanların büyük bir kısmının verimsiz orman, geri kalan kısmının ise verimli orman, mera ve orman toprağı niteliğinde olduğu görülmektedir. 
Yenilenen Karayolu İnşaatları Nedeni ile Oluşan Arazi Tahribatı

Büyük barajların neden olduğu en önemli olumsuz çevresel etkilerinden birisi de şüphesiz ki bu projelerle bağlantılı olarak gerçekleştirilen karayolu ulaşım ağlarının (yol, köprü, viyadük, vb.) yenilenmesidir. Barajların gövde ve benzeri yapıları ile beraber, baraj rezervuarı altında kalan karayollarının daha yüksek kotlara taşınması kaçınılmazdır ve bu durum geniş çaplı inşaat çalışmalarının ortaya çıkmasına ve dolayısı ile ciddi arazi tahribatına neden olmaktadır (Özalp ve ark.
2009; Özalp ve ark. 2012; Yıldırımer ve ark. 2014). Söz konusu tahribatın en önemli nedeni ise yol inşaatları sırasında ortaya çıkan fazla kazı hafriyatının hem Hafriyat Toprağı, İnşaat ve Yıkıntı Atıklarının Kontrolü Yönetmeliğine (RG: 18.03.2004 - 25406) ve hem de Karayolları Genel Müdürlüğü, DSi ve inşaat firmaları arasında yapılan protokollere aykırı olarak gelişigüzel bir şekilde şevlerden aşağı atılmasıdır. Çalışma alanımızı oluşturan ÇNH'nın topoğrafik yapısının dağlık ve yüksek eğimli olması yol yapım çalışmalarındaki bu arazi tahribatının boyutunu arttırmaktadır (Şekil 15).

Tablo 5. Borçka ve Deriner Barajları ile bağlantılı olarak gerçekleştirilen yeni yolların inşaatı nedeni ile tahrip olan arazi şekilleri ve alansal büyüklükleri (ha)

\begin{tabular}{|c|c|c|c|c|}
\hline & & Borçka Barajı ve HES & Deriner Barajı ve HES & TOPLAM \\
\hline \multirow{4}{*}{ 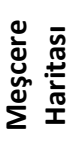 } & Yerleşim Alanları & - & - & \\
\hline & Tarım Alanları & 14.81 & 7.49 & 22.33 \\
\hline & Ormanlar ve Doğal Alanlar & 96.43 & 259.49 & 355.92 \\
\hline & Su Kütleleri & 5.50 & 29.21 & 34.71 \\
\hline \multirow{6}{*}{ ڤ્ટ } & TOPLAM & 116.74 & 296.19 & 412.94 \\
\hline & Yerleşim Alanları & 58.22 & 0.11 & 58.33 \\
\hline & Tarım Alanları & 6.69 & 15.22 & 21.91 \\
\hline & Ormanlar ve Doğal Alanlar & 48.41 & 279.12 & 327.53 \\
\hline & Su Kütleleri & 3.43 & 1.74 & 5.17 \\
\hline & TOPLAM & 116.74 & 296.19 & 412.94 \\
\hline
\end{tabular}

Çalışma alanımızı oluşturan, yapımı tamamlanmış ve enerji üretimine geçmiş olan Borçka ve Deriner Barajları nedeni ile yapılan yeni yol güzergâhlarının oluşturduğu tahribat Tablo 5'te arazi kullanımına göre alansal olarak özetlenmiştir. Söz konusu yol güzergâhları Borçka Barajı için Artvin-Borçka, Deriner Barajı için ise Artvin-Erzurum karayoludur. Yapılan hesaplamalar sonucunda, tüneller dışında kalan karayollarının inşaatları sırasında tahrip olan arazi miktarının yaklaşık 413 ha (Tablo 5) civarında olduğu tahmin edilmiştir.

Yol inşaatları sonucunda ortaya çıkan arazi tahribatını ortaya koyan benzer bir çalışmada (Toker 2010), Deriner Barajı nedeni ile yenilenen Artvin-ŞavşatArdahan karayolunun sadece 20 km'lik bir bölümünün inşası sonucunda yaklaşık 210.10 ha'lık bir alanın artık kullanılamaz hale geldiğini hesaplamıştır.

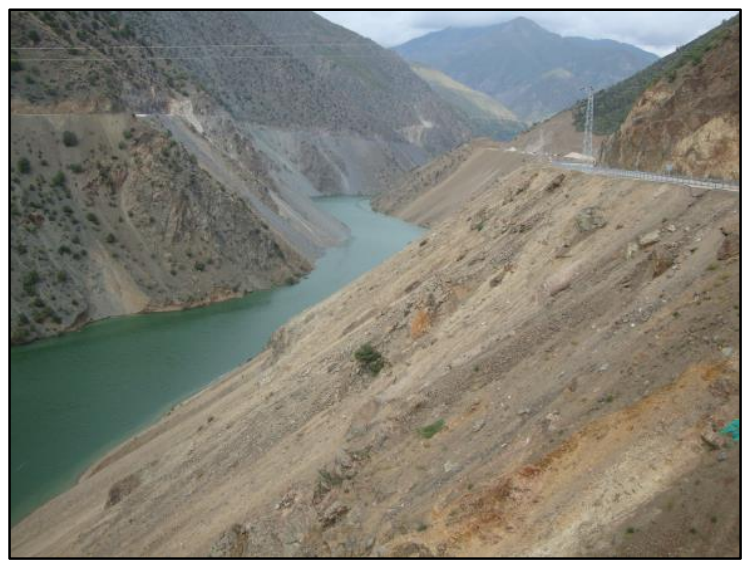

Şekil 15. Büyük barajlar nedeni ile inşa edilen yeni yolların yapımı sırasında ortaya çıkan hafriyatın gelişigüzel bir şekilde şevlerden aşağı atılması sonucunda oluşan tahribat

Tablo 5'ten de görüleceği üzere tahribatın oluştuğu en büyük arazi kullanımının her iki baraj ve her iki harita için ormanlık alanlar olduğu görülmektedir. Ayrıca, yol inşaatları nedeni ile tahrip olan alan içerisinde meşcere haritasına göre yerleşim alanları görülmezken, CLC2006 haritasına göre Borçka ve Deriner Barajları için toplamda 71.49 ha yerleşim alanı olduğu 
görülmektedir. Bunun nedeni ise vadi boyunca tarım alanları ile birlikte dağınık halde bulunan yerleşim birimlerinin meşcere haritasında "Z-i̇s" rumuzu ile ifade edilen tarım ve yerleşim alanları ile beraber gösterilmesidir. Bu alanların ise çoğunluğunu tarım alanlarının teşkil etmesinden dolayı sınıflamada ziraat alanlarına dahil edilerek gösterilmiştir. CLC-2006 haritasında ise tarım ve yerleşim birimlerinin CORINE haritalandırma sistemine göre 5 ha'dan küçük bulunan tarım alanlarının yerleşim birimlerine dahil edilerek gösterilmesinden kaynaklanmaktadır.

Tablo 6. Artvin il sınırları içerisinde planlanan büyük baraj ve HES Tesisleri nedeniyle su altında kalarak kaybolan/kaybolacak arazilerin meşcere ve CLC-2006 haritalarına göre kullanım şekilleri ve alansal büyüklükleri (ha)

\begin{tabular}{|c|c|c|c|c|c|c|c|c|c|c|}
\hline & & $\begin{array}{c}\text { Muratlı } \\
\text { Barajı ve } \\
\text { HES }\end{array}$ & $\begin{array}{c}\text { Borçka } \\
\text { Barajı ve } \\
\text { HES }\end{array}$ & $\begin{array}{c}\text { Deriner } \\
\text { Barajı ve } \\
\text { HES }\end{array}$ & $\begin{array}{c}\text { Artvin } \\
\text { Barajı ve } \\
\text { HES }\end{array}$ & $\begin{array}{c}\text { Yusufeli } \\
\text { Barajı ve } \\
\text { HES }\end{array}$ & $\begin{array}{c}\text { Bayram } \\
\text { Barajı ve } \\
\text { HES }\end{array}$ & $\begin{array}{c}\text { Bağlık } \\
\text { Barajı ve } \\
\text { HES }\end{array}$ & TOPLAM & $\%$ \\
\hline \multirow{4}{*}{ 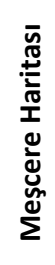 } & $\begin{array}{l}\text { Yerleşim } \\
\text { alanları }\end{array}$ & - & - & 34.8 & 3.7 & 24.1 & 0.1 & - & 62.7 & 0.77 \\
\hline & $\begin{array}{l}\text { Tarım } \\
\text { alanları }\end{array}$ & 159.4 & 167.2 & 469 & 60.4 & 1104 & 82.9 & 1 & 2043.9 & 25.12 \\
\hline & $\begin{array}{l}\text { Ormanlar ve } \\
\text { doğal alanlar }\end{array}$ & 41.5 & 437.3 & 1945.7 & 345.9 & 1974.2 & 262.5 & 35 & 5042.1 & 61.97 \\
\hline & Su kütleleri & 225.2 & 424.7 & 221.5 & - & 116.7 & - & - & 988.1 & 12.14 \\
\hline \multicolumn{2}{|c|}{ Toplam } & 426.1 & 1029.2 & 2671 & 410 & 3219 & 345.5 & 36 & 8137 & \\
\hline \multirow{4}{*}{ 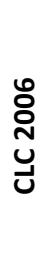 } & $\begin{array}{l}\text { Yerleşim } \\
\text { alanları }\end{array}$ & - & 69.7 & - & - & 26.9 & - & - & 96.6 & 1.19 \\
\hline & $\begin{array}{l}\text { Tarım } \\
\text { alanları }\end{array}$ & 11.5 & 26.2 & 535.6 & 66.2 & 1107.1 & 19.4 & - & 1766 & 21.70 \\
\hline & $\begin{array}{l}\text { Ormanlar ve } \\
\text { doğal alanlar }\end{array}$ & 45.9 & 95 & 1679.6 & 145.6 & 1788 & 326.1 & 36 & 4116.5 & 50.59 \\
\hline & Su kütleleri & 368.7 & 838.3 & 455.5 & 198.2 & 297 & - & - & 2157.7 & 26.52 \\
\hline \multicolumn{2}{|c|}{ TOPLAM } & 426.1 & 1029.2 & 2671 & 410 & 3219 & 345.5 & 36 & 8137 & \\
\hline
\end{tabular}

\section{TARTIŞMA ve SONUÇ}

Barajların kuruldukları akarsu havzasında ekolojik, ekonomik, sosyal ve kültürel değişimlere neden olduğu bir gerçektir. Genellikle gelişmekte olan ülkelerin enerji sağlamak, tarımsal sulama yapmak ve içme/kullanma suyu sağlamak amaçlı tercih ettiği büyük barajlar, ne yazık ki kuruldukları akarsu havzaları üzerinde ciddi alansal değişime ve/veya kayıplara (Toker 2010), ekolojik tahribatlara (Akıncı ve ark. 2012), tarım ve yerleşim alanlarının kullanılamaz hale gelmesine, bazı sosyal (örn: zorunlu göç) sorunlara ve ekonomik farklılaşmalara neden olmaktadırlar. Ayrıca, ağırlıklı olarak ve doğrudan akarsu sistemindeki dere kenarı habitatlarının, su basar alanların, sulak alanların ve dolayısı ile bu alanlara bağlı olarak yaşayan flora ve faunanın büyük oranda yok edilmesine de neden olmaktadırlar (Zhao ve ark. 2006). Ancak, söz konusu projeler nedeni ile meydana gelen bu değişimlerin özellikle Çoruh Nehri vadisi boyunca neden olduğu/olacağı bazı ciddi ekolojik, sosyal ve ekonomik olumsuzlukların yeterince irdelenmediği de açıkça görülmektedir. Örneğin, vadi boyunca yetişen endemik bitki türlerinin çoğunun kaybedilmesi, göç eden yaban hayatı ile ilgili bir çalışmanın yapılmaması, yörede yaşayan halkın önemli bir kısmına alternatif yerleşim yeri önerilmemesi bunlardan bazıları olarak sıralanabilir. Büyük barajların arazi kullanımlarında neden olduğu değişimler arasında doğrudan insanlar ve yaşam alanları üzerinde yaptığı etkiler uzun yıllardır ve halen devam eden bir tartışma konusudur. Bu projelerden bazılarının alternatif gelir kaynakları (örn: balıkçılık ve turizm) yaratabilmesi durumunda yerel halk için ekonomik kazanç olabileceği savına karşın (Fuggle ve ark. 2000), barajların yapıldığı akarsu kenarlarındaki yerleşim yerlerinin ve tarım alanlarının tamamen veya kısmen kaybedilmesi sonucunda yerel halkın zorunlu göçe tabi tutulması ile aslında oldukça 
zarar gördükleri araştırmacılar tarafından belirtilmiştir (Sadler ve ark. 2000).

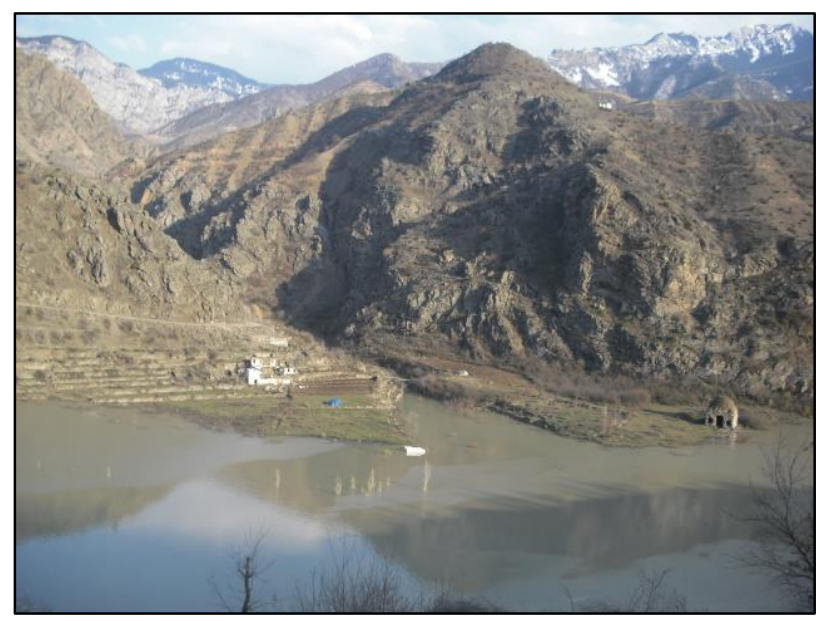

Şekil 12. Büyük barajların su tutma aşamasında yerleşim ve tarım alanlarını rezervuar suları altında bırakarak neden olduğu arazi kayıpları (Deriner Barajı örneği)

Büyük barajların neden olduğu olumsuz etkilerin başında, bu çalışmanın ana amaçlarından birini de oluşturan, arazi kayıpları yer almaktadır (Nilsson ve ark. 2005; Toker 2010; Zhao ve ark. 2010; Zhao ve ark. 2013). Yukarıda detayları verilen ve çalışma alanımızı oluşturan söz konusu 7 büyük barajın tamamının rezervuar alanlarının su ile dolduğu varsayıldığında toplam 8137 ha'lık bir alanın (Tablo 6) sular altında kalacağı tahmin edilmiştir. Diğer bir ifade ile Çoruh Nehri Havzası'nda orman, tarım ve yerleşim gibi farklı amaçlarla kullanılan alanların su alanı olarak değişime uğrayacakları bu araştırma ile ortaya konulmuştur. Arazi kullanımlarında meydana gelen benzer kayıplara ülkemizde çok sayıda örnek göstermek mümkündür (Koçer ve Yılmaz 1994; Sever 2005; Toker 2010). Örneğin, 1975 yılında elektrik enerjisi üretimine başlayan Keban Barajı 650 km²'lik bir alanı sular altında bırakmıştır. Barajın yapılmasıyla 212 yerleşim birimi ve oldukça verimli tarım arazileri sular altında kalarak tarımsal üretimde önemli değişimler veya kayıplar meydana gelmiştir (Şengün 2001). Tarımsal üretim alanları açısından önemli azalmaların yaşandığı başka bir baraj ise Aşağı Kızılırmak Vadisinde yer alan Altınkaya Barajıdır. Bu baraj 1987 yılında su tutmaya başlamış ve 38 köy ile yaklaşık 5400 ha verimli tarım arazisini tamamen veya kısmen etkilemiştir (Şahin 2000). Benzer şekilde Kızılırmak üzerinde kurulmuş olan Derbent Barajı da 1991 yılında faaliyete geçtiğinde 200 evi, yaklaşık $17 \mathrm{~km}^{2}$ büyüklüğünde tarım alanını ve tarihi ikiztepe Şehrini sular altında bırakmıştır (Sönmez 2012).

Çalışma alanımıza benzer şekilde ülkemizde yapılmış, inşası devam eden ve planlama aşamalarında olan baraj projelerinden biri de Güneydoğu Anadolu Projesi (GAP) olarak sayılabilir. Güneydoğu Anadolu Projesi (GAP) kapsamında Dicle Nehri üzerinde inşa edilecek Ilısu Barajı ve HES ile 1 ilçe, 30 köy ve 49 mezrada yaşayan yaklaşık 20 bin nüfus göç etmek zorunda kalacaktır (Akkaya ve ark. 2009). Yine GAP çerçevesinde Kahta Çayı ve kolları üzerinde bazı barajların yapılması planlanmış ve tüm barajların inşa edildiği varsayıldığında havzanın \%2,3’ü (3682 ha) gibi büyük bir alanın sular altında kalacağı tahmin edilmiştir (Elmastaş 2008).

$\mathrm{Bu}$ çalışmada uygulanan yöntem çerçevesinde araştırma alanında meydana gelen/gelecek arazi kayıplarının alansal açıdan belirlenmesinde hem meşcere hem de CLC-2006 haritaları kullanılmıştır. Tablo 6'da yer alan veriler ışığında her iki haritadan elde edilen değerlerin birbirinden farklı olduğu görülmektedir. Bu durum, Borçka, Deriner ve Artvin barajlarının kamulaştırma/istimlak çalışmalarından alınan gerçek alan verileri ile karşılaştırıldığında daha da açıktır (Tablo 1, 2, 3). Her iki haritaya göre kamulaştırma verilerinin belirgin şekilde farklı olmasının ana nedenlerinden birisinin kamulaştırmaya dahil olmayan ancak bu çalışmada kullanılan meşcere ve CLC2006 haritalarında yer alan tescil dışı (su yüzeyleri, kayalık-taşlık alanlar, yollar, şalt sahaları) alanların bulunması olarak açıklanabilir.

Meydana gelen/gelecek kayıp miktarlarının vasıflarına göre listelendiği Tablo 6 incelendiğinde, en büyük kaybın orman ve doğal alanlar vasfındaki alanlar üzerinde olduğu görülmektedir. Söz konusu orman ve doğal alanlar meşcere haritasına göre 5042.1 ha, CLC2006 haritasına göre ise 4116.5 ha'dır. Her iki haritada 
da orman ve doğal alanlar olarak gösterilen miktarlar arasındaki bu farkın meşcere haritasında nehir yatağının gösterilmemesinden kaynaklanmış olabileceği düşünülmektedir. Ayrıca, tahrip olan arazilerden orman ve doğal alanlar kategorisinde kalan alanların önemli bir bölümünün verimsiz orman, diğer bölümlerinin ise verimli orman, mera ve orman toprağı niteliğinde olduğu Tablo 4'ten de açıkça görülmektedir. Ancak, bu çalışmaya konu olan büyük barajlar nedeni ile kaybolan ormanlık alanların çoğunlukla "verimsiz orman" vasfında olması, bu alanların özellikle su üretme, toprağı erozyona karşı koruma, bazı endemik türlere yaşam ortamı sağlama, yaban hayatına destek olma ve peyzaj değeri sunma vb. birçok işlevi yerine getirmediği anlamına gelmemelidir. Aksine, ÇNH'nın özellikle orta ve yukarı kısımlarını oluşturan bölümlerindeki sarp arazi yapısı ve bozuk ve zayıf bitki örtüsü nedeni ile yukarıda bahsi geçen fonksiyon ve yararların önemi daha da artmaktadır.

Tarım alanlarına bakıldığında ise meşcere haritasına göre 2043.9 ha, CLC-2006 haritasına göre 1766 ha tarımsal arazinin sular altında kalarak kaybolacağı tahmin edilmektedir. Ortaya çıkan bu farkların ana nedenlerinden biri, tarım alanlarının vadi boyunca dağınık halde bulunması gerçeği ile ilişkilendirebilir. Diğer bir ifade ile CORINE haritalandırma sistemine göre 25 ha'dan küçük alanlar haritalandırmaya dahil edilmediğinden münferit olarak 25 ha'dan küçük bulunan tarım alanları, komşu bulunan orman alanlarına dahil edilerek haritalandırı mıştır ki bu da CLC2006 tarafından su altında kaldığı/kalacağı tahmin edilen toplam tarım alanı miktarını düşürmüş olabilir (Tablo 6). Ayrıca meşcere haritalarında ziraat-iskân olarak ifade edilen yerleşim ve tarım alanlarının bir arada bulunduğu alanlar yapılan sınıflamada tarım alanlarına dâhil edilmiştir.

Büyük barajların yapımı sırasında neden olunan geniş çaplı arazi kayıplarına, yine bu yapılarla bağlantılı olarak gerçekleştirilen çok sayıda ve uzun mesafeleri kapsayan karayolu ağlarının yenilenmesine yönelik inşaat çalışmalarını ve bu çalışmalar sırasında oluşan arazi tahribatlarını da eklemek gerekmektedir (Özalp ve ark. 2009; Toker 2010). Araştırma sahamız olan ÇNH içerisinde yol inşaatlarının neden olduğu arazi tahribatlarını genel bir hesaplama ile ortaya çıkarmak üzere yapımı tamamlanmış ve enerji üretimine geçmiş olan Borçka ve Deriner Barajları örnek olarak seçilmiş ve yapılan hesaplamalar sonucunda, tüneller dışında kalan karayollarının inşaatları sırasında tahrip olan arazi miktarının yaklaşık 413 ha (Tablo 5) civarında olduğu tahmin edilmiştir. Ancak, ÇNH'da planlanan toplam büyük baraj sayısının 15 olduğu ve anayollarla beraber barajlardan etkilenen diğer yerleşim yerlerine (ilçeler, köyler, vb.) olan bağlantı yollarının da yenilenmesi zorunluluğu göz önünde bulundurulduğunda karayolu inşaatları nedeni ile ortaya çıkan söz konusu tahribatın çok daha artacağı kaçınılmazdır. Arazi tahribatlarının oldukça yüksek oranlarda çıkmasının nedenleri arasında bölgedeki topoğrafik yapının oldukça dağlık ve dik eğimli olması (Tunay ve ark. 2008) yanında inşaatların mevzuata (Hafriyat Toprağı, İnşaat ve Yıkıntı Atıklarının Kontrolü Yönetmeliği) aykırı bir şekilde yürütülmesi ve denetimlerin yetersiz ve caydırıcılıktan uzak olması sıralanabilir. Yenilenen karayollarının neden olduğu arazi tahribatının bir diğer olumsuz sonucu da bu alanlar üzerinde önemli miktarda finansal ve iş gücü kaynağı harcanarak yapılan erozyon kontrol ve ağaçlandırılma çalışmalarıdır (Özalp ve ark. 2009; Dehşet 2011). Ancak, bu tip çalışmalarda; arazinin oldukça eğimli olmasından dolayı ortaya çıkan fidan dikim zorlukları, fidanların yaşam yüzdelerindeki düşüklük, yöreye ait doğal türlerin tercih edilememesi, fidan türü ve sayısındaki yetersizlik gibi çok sayıda sorunla karşılaşıldığı da unutulmamalıdır.

Sonuç olarak, hem barajlar hem de yeni yol inşaatları nedeni ile Çoruh Nehri Havzasında farklı kullanım amaçlarına hizmet eden önemli miktarda arazinin kayba uğradığı veya tahrip edildiği ortaya çıkmıştır. Dolayısı ile bu tip büyük projelerin daha detaylı irdelenerek planlanması ve Çoruh Nehri Havzası 
örneğinde olduğu gibi meydana gelen çok sayıda ciddi olumsuzluğun en aza indirgenmesi amacı ile daha kapsamlı ve bilimsel verilere dayanan çalışmaların yapılması gerekmektedir.

\section{KAYNAKLAR}

Akıncı H, Y Özalp A, Turgut B (2012) AHP Yöntemi İle Tarıma Uygun Alanların Belirlenmesi, IV. Uzaktan Algılama ve Coğrafi Bilgi Sistemleri Sempozyumu (UZAL-CBS 2012), 16-19 Ekim 2012, Zonguldak

Akkaya U, Gültekin A B, Dikmen Ç B, Durmuş G (2009) Baraj ve Hidroelektrik Santrallerin (HES) Çevresel Etkilerinin Analizi: Ilısu Barajı Örneği. 5. Uluslararası İleri Teknolojiler Sempozyumu, 19-15 Mayıs Karabük

Bayram M, Hazar T (1994) Baraj Projelerinde Kamulaştırmanın Sebep Olduğu Sosyal ve Çevresel Etkiler, DSi Genel Müdürlüğü 40'ıncı Kuruluş Yılı (1954-1994) Su ve Toprak Kaynaklarının Geliştirilmesi Konferansı Bildirileri, Cilt 3, s. 1175-1182, Ankara

Bossard M, Feranec J, Otahel J (2000) Corine Land Cover Technical Guide - Addendum. European Environment Agency, Technical report No:40, Copenhagen, Denmark

Dehşet F (2011) Baraj Ve Yol İnşası Nedeniyle Tahrip Edilen Alanlarda Yapılan Erozyon Kontrol Çalışmalarının Toprak Özelliklerinin İyileştirilmesi Üzerine Etkilerinin İrdelenmesi. Artvin Çoruh Üniversitesi, Fen Bilimleri Enstitüsü, Yüksek Lisans Tezi

DSi (2007) Devlet Su İşleri Genel Müdürlüğü. 2007 Faaliyet Raporu. http://www.dsi.gov.tr

DSi (2011) Haritalı İstatistik Bülteni (2011). Devlet Su İşleri Genel Müdürlüğü, Strateji Geliştirme Dairesi Başkanlığı. Genel Yayın No : 991. DSi Destek Hizmetleri Dairesi Başkanlığı, Basım ve Foto-Film Şube Müdürlüğü, Ankara. http://www.dsi.gov.tr/yayinlarimiz

Dudgeon D (1995) River regulation in Southern China: Ecological implications, conservation and environmental management. Regul. Rivers: Res. Mgmt., 11: 35-54. doi: 10.1002/rrr.3450110105

Duran C (2005) Hazar Gölü Havzası Arazi Kullanımındaki Değişikliklerin Belirlenmesi, Fırat Üniversitesi Sosyal Bilimler Enstitüsü, Yüksek Lisans Tezi

Elmastaş N (2008) Kahta Çayı Havzası'nda Arazi Kullanımı. Coğrafi Bilimler Dergisi, 6(2), 159-190.

Fuggle R, Smith T W (2000) Large Dams in Water and Energy Resource Development in the People's Republic of China (PRC). Country Review Paper Prepared as an Input to the World Commission on Dams, Cape Town

Genç L, Bostancı Y B (2007) TROiA Milli Parkı Arazi Kullanım ve Bitki Örtüsü Değişiminin Uzaktan Algılama ve Coğrafi Bilgi Sistemi Yardımıyla Belirlenmesi, Tekirdağ Ziraat Fakültesi Dergisi, 2007 $4(1)$

Güler M, Yomralığlu T, Reis S (2007) Using Landsat data to Determine Land Use/Land Cover Changes in Samsun, Turkey. Environmental Monitoring and Assessment, 127(1-3), 155-167

Gündoğan R, Yüksel A, Akay A E, Bozali N, Doğan O (2008) Arazi Kullanım Planlamasının Erozyon Kontrol Çalışmalarındaki Önemi: Kartalkaya Baraj Havzası Örneği, Baraj Havzalarında Ormancılık, I. Ulusal Sempozyumu, s.331-347, Kahramanmaraş
İnan M, (1998) Yeniçiftlik Deresi (Beykoz) Yağış Havzasında Arazi Kullanımındaki Değişimlerin Akım Üzerine Etkileri, İstanbul Üniversitesi Fen Bilimleri Enstitüsü, Orman Müh. Abd., Yüksek Lisans Tezi

Karakılçık Y, Koç F (2012) Munzur Suyu Projelerinin Bölgesel Kalkınma Açısından İrdelenmesi. Paper presented at the 2 . Turgut Özal Uluslararası Ekonomi ve Siyaset Kongresi, Malatya.

Kellogg C H, Zhou X (2014) Impact of the construction of a large dam on riparian vegetation cover at different elevation zones as observed from remotely sensed data. International Journal of Applied Earth Observation and Geoinformation, 32(0), 19-34

Kılıç T, Koca Y K, Doran I (2007) Bağıvar'da Arazi Kullanımının Corine Programına Göre Değerlendirilmesi, Marmara Coğrafya Dergisi, Sayı:16, Temmuz-2007, İstanbul

Koçer A Ü, Yılmaz Ö (1994) Hidroelektrik Santrallerin Çevresel Etkileri, DSi Genel Müdürlüğü 40'ıncı Kuruluş Yılı (1954-1994) Su ve Toprak Kaynaklarının Geliştirilmesi Konferansı Bildirileri, Cilt 3, s. 1139-1144, Ankara

Maingi J K, Marsh S E (2002) Quantifying hydrologic impacts following dam construction along the Tana River, Kenya, Journal of Arid Environments (2002) 50: 53\}79, doi:10.1006/jare. 2000.0860

Nilsson C, Reidy C A, Dynesius M, Revenga C (2005) Fragmentation and Flow Regulation of the World's Large River Systems, Science 308, 405, DOI: 10.1126/science.1107887

Onur I, Matkav D, Sarı M, Sönmez N M (2009) Change detection of land cover and land use using remote sensing and GIS: a case study in Kemer, Turkey International Journal of Remote Sensing Vol. 30, No. 7, 10 April 2009, 1749-1757

Özalp M, Yavuz A, Yüksek T, Toker E (2009) Baraj ve Yol Yapımlarının Doğal Kaynaklara Etkisi: Aşağı Çoruh Havzası Örneği / Influences of Dam and Road Construction on Natural Resources: Case Study for the Lower Coruh Basin. II. Ulusal Baraj Güvenliği Sempozyumu Bildiri Kitabı. 13-15 Mayıs 2009. Eskişehir

Özalp M, Erdoğan Yüksel E, Yıldırımer S (2012) CBS Yardımı ile Çoruh Nehri Üzerinde Planlanan Baraj ve Yol Projelerinin Neden Olacağı Arazi Kullanım Değişiminin ve Arazi Tahribatının Belirlenmesi, IV. Uzaktan Algılama ve Coğrafi Bilgi Sistemleri Sempozyumu (UZAL-CBS 2012)

Sadler B, Verocai I, Vanclay F (2000) Environmental and Social Impact Assessment for Large Scale Dams. WCD Thematic Review V.2 Prepared as an Input to the World Commission on Dams. WCD, Cape Town

Sever R (2005) Çoruh Nehri Enerji Yatırım Projeleri ve Çevresel Etkileri, Çizgi Kitabevi, Konya

Sever R (2010) "Yusufeli Barajı ve Bazı Çevresel Etkileri" Geçmişten Geleceğe Yusufeli Sempozyumu Bildirileri, ISBN: 978-60588588-0-0

Sönmez M E (2012) Barajların Mekân Üzerindeki Olumsuz Etkileri ve Türkiye'den Örnekler. Gaziantep Üniversitesi Sosyal Bilimler Dergisi, 11(1), 213-231

Sönmez N K, Sarı M (2004) Coğrafi Bilgi Sistemleri Temel Esasları Ve Uygulama Alanları, Derim, 21(1), 54-68.

Şahin K (2000) Altınkaya Baraj Gölü Suları Altında Kalan Köylerden Göç Edenlerin Karşılaştıkları Sorunlar ve Vezirköprü Şehrine Etkileri. Eskişehir Osmangazi Üniversitesi Sosyal Bilimler Dergisi, 1(1) 
Şengün M T (2001) Barajların Çevresel Etkileri ve Keban Barajı Örneği. IV. Ulusal Ekoloji ve Çevre Kongresi, 5-8 Ekim Bodrum

Şensoy H (2002) Bartın İli Aşağıdere Havzası'nda Arazi Kullanımı Değişiminin Belirlenmesi ve Arazi Kullanımının Bazı Fiziksel Havza Karakteristikleri Yönünden Değerlendirilmesi, Zonguldak Karaelmas Üniversitesi Fen Bilimleri Enstitüsü, Yüksek Lisans Tezi

Toker E (2010) Borçka Ve Deriner Barajlarının Çoruh Havzasında Neden Olduğu Arazi Kullanım Değişiminin Ve Arazi Tahribatının İrdelenmesi, Yüksek Lisans Tezi, Artvin Çoruh Üniversitesi, Fen Bilimleri Enstitüsü, Orman Mühendisliği Anabilim Dalı, Artvin.

Wang B, Zheng F, Römkens M J M, Darboux F (2013) Soil erodibility for water erosion: A perspective and Chinese experiences. Geomorphology. 187: 1-10

WCD (2000) Dams and Development: A New Framework for Decision-Making. The Report of the World Commission on Dams. Earthscan Publications Ltd, London and Sterling, VA

Yıldırımer S (2013) Çoruh Nehri Üzerinde Tamamlanan, İnşası Devam Eden ve Planlanan Büyük Barajların Neden Olduğu ve
Olacağı Arazi Kullanım Değişimlerinin Belirlenmesi. Artvin Çoruh Üniversitesi, Fen Bilimleri Enstitüsü, Yüksek Lisans Tezi

Yıldırımer S, Özalp M, Erdoğan Yüksel E (2014) Çoruh Nehri Üzerindeki Baraj Projelerinin Neden Olduğu Arazi Kullanım Değişiminin Corine Arazi Örtüsü ve Meşcere Haritaları Kullanılarak Belirlenmesi, I. Ulusal Havza Yönetimi Sempozyumu, 2014

Zhao Q, Liu S, Deng L, Dong S, Yang Z, Liu Q 2013 Determining the influencing distance of dam construction and reservoir impoundment on land use: A case study of Manwan Dam, Lancang River, Ecological Engineering 53 (2013) 235- 242.

Zhao Q, Liu S, Dong S (2010) Effect of Dam Construction on SpatialTemporal Change of Land Use: A Case Study of Manwan, Lancang River, Yunnan, China, International Society for Environmental Information Sciences 2010 Annual Conference (ISEIS), Procedia Environmental Sciences 2 (2010) 852-858.

Zhao S, Peng C, Jiang H, Tian D, Lei X, Zhou X (2006) Land use change in Asia and the ecological consequences. Ecological Research, 21(6), 890-896 